\title{
Commentary on Pilot Trial of a Novel Two-Step Therapy Protocol Using Nebulized Tranexamic Acid and Recombinant Factor VIIa in Children with Intractable Diffuse Alveolar Haemorrhage
}

\section{Hind Bafaqih* and Farah Thabet}

Pediatric Intensive Care, Prince Sultan Military Medical City, Riyadh, KSA, Saudi Arabia

The cases presented here is an initiative trial in the management of diffuse alveolar hemorrhage (DAH) in a noninvasive method [1]. In the evaluation and treatment of a pediatric patient with pulmonary hemorrhage, a three step approach may be the straightest forward. The physician must prevent asphyxiation, stop the bleeding, and treat the underlying cause [2] This study aimed at exploring the feasibility and efficacy of nebulized tranexamic acid TXA (n-TXA) and nebulized recombinant factor VIIa (n-rFVIIa) when used in a two-step therapy protocol in children with intractable DAH in a pediatric intensive care unit. In this prospective trial, n-TXA $(250 \mathrm{mg} /$ dose for children $<25 \mathrm{~kg}$ and $500 \mathrm{mg} /$ dose for children $>25 \mathrm{~kg}$ ) was administered to 18 children (median age 24.0 months $[11.3,58.5]$ ) with intractable DAH. N-rFVIIa $(35 \mu \mathrm{g} / \mathrm{kg} / \mathrm{dose}$ for children $<25 \mathrm{~kg}$, and $50 \mu \mathrm{g} / \mathrm{kg} / \mathrm{dose}$ for children $>25 \mathrm{~kg}$ ) was added if no or minimal response was seen after 3 to 4 doses (18 to 24 hours) of n-TXA. DAH was stopped in 10 (55.6\%) children with n-TXA alone within 24 hours of therapy. In the other $8(44.4 \%)$ children, n-rFVIIa was added due to n-TXA failure. Six (75.0\%) showed complete cessation of DAH, while two children failed to respond with the addition of $\mathrm{n}$-rFVIIa $(25.0 \%)$. None of the children who responded to therapy showed recurrence of DAH after therapy termination. Documented concomitant respiratory infection showed a significant negative association with response to n-TXA in a stepwise regression analysis $(\mathrm{OR}=0.06 ; 95 \% \mathrm{CI}=0.01-0.74)$. No complications related to therapy were recorded [3-6].

Tranexamic acid (TXA), a synthetic derivative of the amino acid lysine, is an anti-fibrinolytic agent that exerts its action through binding to plasminogen preventing its binding to fibrin and hence its activation to plasmin [7]. TXA was also successful in controlling bleeding when directly administered intrapleurally [8] and into the pericardial cavity [9].

Recombinant factor VIIa (rFVIIa) is a hemostatic agent that achieves hemostasis by one of two mechanisms:

1) Activating factors $X$ and IX at sites of tissue injury through binding to tissue factor (TF) and activated platelets resulting in thrombin generation;

2) TF-independent mechanism, in which rFVIIa directly activates factor X on the surface of activated platelets [10]. There is an increasing interest in off-label use of intravenous rFVIIa in children with clinical bleeding due to non-hemophilic reasons [11], including DAH in newborns [12] and children [13].

Recently, two case reports were published in which DAH was treated by direct intrabronchial rFVIIa instillation in children $[14,15]$. Several cases reported the successful use of rFVIIa locally administered through bronchoscope to adults with DAH. One case in was given rFVIIa through nebulization after failure of intravenous rFVIIa [16], Direct intrabronchial instillation was the primary method of drug delivery in all reports [17-19].

This preliminary clinical trial confirmed the feasibility of n-TXA and n-rFVIIa when used in a two-step therapy protocol to control intractable DAH in PICU settings. The two drugs as used in this study showed an excellent risk/benefit profile that warrants further exploration through a larger multicenter prospective double blind randomized clinical trial which we are currently planning to start.

\section{References}

1. Bafaqih H, Chehab M, Almohaimeed S, Thabet F, Alhejaily A, et al. (2015) Pilot trial of a novel two-step therapy protocol using nebulized tranexamic acid and recombinant factor VIla in children with intractable diffuse alveolar hemorrhage. Ann Saudi Med 35: 231-239.

2. Gaude GS (2010) Hemoptysis in children. Indian Pediatr 47: 245-254

3. Mannucci PM (1998) Hemostatic drugs. N Engl J Med 339: 245-253.

4. De Boer WA, Koolen MG, Roos CM, Ten Cate JW (1991) Tranexamic acid treatment of hemothorax in two patients with malignant mesothelioma. Chest 100: 847-848.

5. De Bonis M, Cavaliere F, Alessandrini F, Lapenna E, Santarelli F, et al. (2000) Topical use of tranexamic acid in coronary artery bypass operations: a doubleblind, prospective, randomized, placebo-controlled study. J Thorac Cardiovasc Surg 119: 575-580.

6. Hedner U (2006) Mechanism of action, development and clinical experience of recombinant FVIla. J Biotechnol 124: 747-757.

7. Huaringa AJ, Leyva FJ, Signes-Costa J, Morice RC, Raad I, et al. (2000) Bronchoalveolar lavage in the diagnosis of pulmonary complications of bone marrow transplant patients. Bone Marrow Transplant 25: 975-979.

8. Specks U (2001) Diffuse alveolar hemorrhage syndromes. Curr Opin Rheumatol 13: 12-17.

9. Sindet-Pedersen S, Ramström G, Bernvil S, Blombäck M (1989) Hemostatic effect of tranexamic acid mouthwash in anticoagulant-treated patients undergoing oral surgery. N Engl J Med 320: 840-843.

10. McQuilten ZK, Barnes C, Zatta A, Phillips LE; Haemostasis Registry Steering Committee (2012) Off-label use of recombinant factor VIla in pediatric patients. Pediatrics 129: e1533-1540.

11. van Ommen $\mathrm{CH}$, Peters $\mathrm{M}$, Barth PG, Vreken $\mathrm{P}$, Wanders RJ, et al. (2000) Carbohydrate-deficient glycoprotein syndrome type 1a: a variant phenotype with borderline cognitive dysfunction, cerebellar hypoplasia, and coagulation disturbances. J Pediatr 136: 400-403.

12. Gkiougki E, Mitsiakos G, Chatziioannidis E, Papadakis E, Nikolaidis N (2013) Predicting response to $\mathrm{rFVIla}$ in neonates with intractable bleeding or severe coagulation disturbances. J Pediatr Hematol Oncol 35: 221-226.

13. Yilmaz D, Karapinar B, Balkan C, Akisü M, Kavakli K (2008) Single-center experience: use of recombinant factor VIla for acute life-threatening bleeding in children without congenital hemorrhagic disorder. Pediatr Hematol Oncol 25: 301-311.

*Corresponding author: Hind Bafaqih, Pediatric Intensive Care, Prince Sultan Military Medical City, Riyadh, KSA, Saudi Arabia, Tel: 966555558218; E-mail hbafagih13@gmail.com

Received December 17, 2015; Accepted December 22, 2015; Published December 28, 2015

Citation: Bafaqih H, Thabet F (2015) Commentary on Pilot Trial of a Novel TwoStep Therapy Protocol Using Nebulized Tranexamic Acid and Recombinant Factor VIla in Children with Intractable Diffuse Alveolar Haemorrhage. J Pulm Respir Med 5: 305. doi:10.4172/2161-105X.1000305

Copyright: $\odot 2015$ Bafaqih $\mathrm{H}$, et al. This is an open-access article distributed under the terms of the Creative Commons Attribution License, which permits unrestricted use, distribution, and reproduction in any medium, provided the original author and source are credited. 
Citation: Bafaqih H, Thabet F (2015) Commentary on Pilot Trial of a Novel Two-Step Therapy Protocol Using Nebulized Tranexamic Acid and Recombinant Factor VIla in Children with Intractable Diffuse Alveolar Haemorrhage. J Pulm Respir Med 5: 305. doi:10.4172/2161-105X.1000305

14. Larcombe PJ, Kapur N, Fraser CJ, Coulthard MG, Schlapbach LJ (2014) Intrabronchial administration of activated recombinant factor VII in a young child with diffuse alveolar hemorrhage. Pediatr Blood Cancer 61: 570-571.

15. Colin AA, Shafieian M, Andreansky M (2010) Bronchoscopic instillation of activated recombinant factor VII to treat diffuse alveolar hemorrhage in a child. Pediatr Pulmonol 45: 411.

16. Almomen A, Aleem A, Alshaik M, Hasanato R (2014) Intrapulmonary rFVII a for life threatening pulmonary hemorrhage in a case of relapsing acute lymphoblastic leukemia and platelet refractoriness. Platelets 25: 452-454.
17. Heslet L, Nielsen JD, Levi M, Sengeløv H, Johansson PI (2006) Successful pulmonary administration of activated recombinant factor VII in diffuse alveolar hemorrhage. Crit Care 10: R177.

18. Henke D, Falk RJ, Gabriel DA (2004) Successful treatment of diffuse alveolar hemorrhage with activated factor VII. Ann Intern Med 140: 493-494.

19. Estella A, Jareño A, Fontaina PBL (2008) intrapulmonary administration of recombinant activated factor VII in diffuse alveolar haemorrhage: a report of two case stories. Cases J 1: 150 